\title{
Liderando por valores
}



Vicky Bloch DBM do Brasil
$\mathbf{E}$ m um mundo empresarial convulsionado pelo processo de globalização, por crises, fortes oscilações econômicas, processos radicais de mudança e pressões crescentes por resultados, cabe perguntar: qual deve ser o papel e como deve ser a conduta do executivo principal?

Deinício, é preciso frisar que, apesar demaestros dos processos de mudança, os CEOs - Chief Executive Officers - são também atingidos por esses processos. Uma pesquisa promovida pelaDBM, consultoriainternacional cujaatividade presido na América Latina, com 481 empresas em 25 países, revela que quase $60 \%$ delas promoveram pelo menos uma troca de CEO entre 1998 e 2001. Outro número inquietador: nesse mesmo período, $28 \%$ dos executivos principais das organizações pesquisadas aceleraram suas aposentadorias. Aparentemente, esses administradores quiseram se afastar de uma dinâmica empresarial cruel até mesmo para eles próprios, supostos líderes do mundo corporativo.

0 problema começa com a (limitada) extensão da carreira. A pesquisa da DBM constatou que hoje o executivo principal permanece, em média, menos de três anos no posto. Ou seja: não seconcede tempo para que ele assuma o completo controle da organização, crie um padrão de gestão adequado efaça a máquina funcionar a seu modo. Pela prática, sabe-se que oS CEOs precisam de quatro a sete anos para chegar ao nível tido como ideal de liderança e coordenação.
A pressão por resultados decurtíssimo prazo, exercida com voracidade cada vez maior por acionistas e investidores, éa causa central dessa situação. 0 que se vêsão gestões cada vez mais impessoais, em que sucessivas trocas de executivos de diferentesáreas precedem a saída do próprio CEO.

Acredito que a solução para que o CEO atenda às pressões corporativas eao mesmo tempo preserve as pessoas sob sua liderança vem de outra direção. 0 executivo principal deve ter uma escala de valores elevados e tornar seu cumprimento uma marca de sua gestão. Só dessa forma obterá comprometimento e criará um ambiente de liberdade para ousar condição essencial para a inovação e a competitividade. Nafaltadetais condições, costumaocorrer um processo doloroso quechamo de "comoditização do sofrimento": o vínculo afetivo entre indivíduos e organização éabal ado, o nível de comprometimento é reduzido, as pessoas passam a evitar assumir riscose o desempenho éprejudicado. Com isso, o resultado acaba contrariando a expectativa dos acionistas.

Dirigentes empresariais íntegros e focados em resultados têm grande chance de diferenciação no mercado. Quem inspira confiança podeexigir mais, e consegue êxito em processos complexos como a condução de grandes mudanças. 0 mundo transforma-se, as exigências aumentam, mas o ser humano continua o mesmo: sob a autoridade dos duroseindiferentes produz menos epior. Serábemsucedido o executivo principal que tiver firmeza e cultivar a generosidade, aquele que liderar genuinamente, com baseem valores claros e partilhados. 